Teknomekanik

Vol.1, No.2, December 2018, pp. 38 42

\title{
Design and Testing of Belt Grinding Development
}

\author{
Sepdirama Setiawan, Arwizet, Budi Syahri, Ambiyar, Darmawi and Yufrizal
}

Jurusan Teknik Mesin, Fakultas Teknik, Universitas Negeri Padang, Indonesia

\begin{tabular}{l} 
Article Info \\
\hline Article history: \\
Received June $18^{\text {th }}, 2018$ \\
Revised November $23^{\text {th }}, 2018$ \\
Accepted December $05^{\text {th }}, 2018$ \\
\hline Keywords: \\
Belt burrs \\
Stainless steel \\
ST 37 \\
Wood \\
Speed \\
Time
\end{tabular}

Corresponding Author:

Sepdirama Setiawan,

Jurusan Teknik Mesin, Fakultas Teknik, Universitas Negeri Padang

Jln. Prof. Dr. Hamka Air Tawar, Padang (25131), Sumatera Barat, Indonesia

Email: sepdirama.setiawan@gmail.com

\begin{abstract}
The author observes that the use of belt grinding is still rare in the writer's own environment, both in the field of education, and in small industries, because there are still many people who are fixated on ordinary grinders, and think that ordinary grinders are better in all work. The development of belt grinders has changed people's perspectives through the development that the authors have done, with the increase in belt grinding functions through development which will certainly make belt grinders even more useful. This belt burrs are made and developed through pre-existing belt grinding shapes. The result of this development is a belt grinder which has a function more than the belt grinder which is already before. This belt burrs has three types of work functions, namely vertical, horizontal, and cutter, and also features speed control. With the development that the author does, of course, it will change the perspective of people because the belt grinding has a function that is better than before and can better help the work of a grinding process.
\end{abstract}

\section{INTRODUCTION}

Humans want a life without problems, life is better and safer, from human desires this is the development of technology [1]. Age development is a determining factor in how human life in the future, the determinant factor of this development is the technology that describes how advanced human beings at one time, the more sophisticated technology used by humans, the more facilitated human activities are to complete a job. In the world of industry or education, there is still some equipment that is still incomplete or rarely used like one of them is a belt grinding. Belt burrs have their own advantages in several types of work, but still, belt grinders are rarely used, one of the factors is the shape and function of the existing belt grinding are considered too minimal and makes people choose to use other grinders. The development of belt grinding is needed. This is because if a belt grinder has more function, it will certainly make the attraction of grinding work to use the belt grinder, using a belt grinder will certainly provide benefits to the user because the belt grinding efficiency is good in certain operations. The development of belt grinders that I have done is expected to improve the existing belt grinding function, with the existence of belt grinders that have been developed, it is expected to make the education or industrial fields use belt grinders which have been developed because they can facilitate some types grinding work.

\section{METHOD}

This study uses an experimental method, in this final project the development of a belt grinder model and testing of belt grinder models. This is in line with the opinion [2] "experimental research method is a way to find causal relationships (causal relationships) between two factors deliberately caused by research by eliminating or reducing or eliminating other disturbing factors". Research experiments are aimed at knowing the consequences of a given treatment. [3]. Experimental research is a method to determine the effect of treatment on others in controlled conditions. The object of the study under study is a belt grinding machine that has been developed through the manufacture that has been carried out and carried out grinding tests on three types of objects: Stainless Steel, ST37 Steel, and Wood with the same speed and same time. Test 
materials, namely Stainless Steel, ST37 Steel, and Wood used are made of the same size in the touch area of the belt sandpaper sharpening media to obtain accurate test results.

The following is a table of trial material data used in testing belt grinding machines which can be seen in table 1.

Table 1. Test Material Data

\begin{tabular}{lll}
\hline \multicolumn{1}{c}{ Stainless Steel } & \multicolumn{1}{c}{ ST37 } & \multicolumn{1}{c}{ Wood } \\
\hline $\begin{array}{l}\text { Stainless Steel used is a kitchen knife with a } \\
\text { knife size of 30x40x2 mm }\end{array}$ & Steel ST 37 used is a plate & The wood used is teak \\
& with a size of 110x40x2 mm & wood with a size of \\
& & $115 \times 40 \times 2 \mathrm{~mm}$ \\
\hline
\end{tabular}

\section{RESULT}

The results of the research that the authors did were in the form of a belt grinding machine that was used for various purposes of grinding and grinding work. One of the main steps of this research is to make a tool from the development design that I have made one by one until the tool can work. Making continues in the final stage, namely Finishing, Finishing is a process of grinding / smoothing all components made and until the painting process [4]. Belt burrs made using electric power through a 220 Volt 2 Phase electric motor, this is one of them due to savings in the use of fuel oil, because of the limited price and availability of petroleum. The world energy crisis since 1973, especially oil, is still felt today. [5] this affects the economy of the world, of course, including Indonesia. Another thing is Indonesia's national energy needs are very fragile, this will make Indonesia the world's largest oil importer [6]. The following below are the results of the research that has been carried out, one of which is a tool that can be seen in Figure 1.

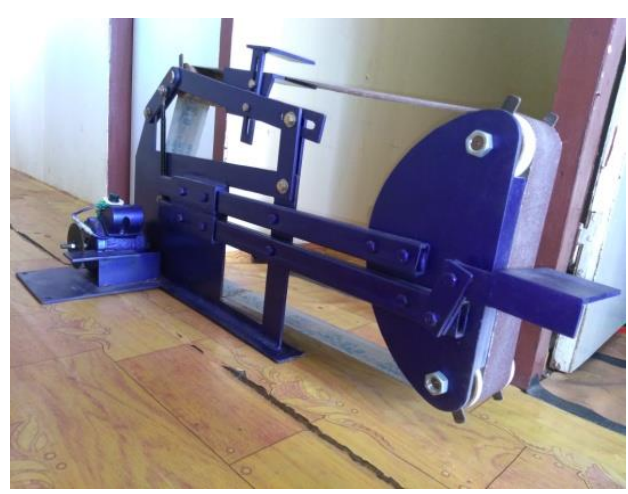

\section{DISCUSSION}

Fig. 1. Belt Belts That Have Been Made

The speed of the belt sandpaper greatly affects how thick the dip is produced from the grinding using a belt grinding machine. This is because the faster the rotation, the less time the sandpaper is needed to scrape. In addition, there are still many other factors that determine the grinding speed such as the sandpaper grid used, the type of material being sharpened, and the size of the honed material. Grinding is a tool that serves to cut with an abrasive process with friction between abrasive with objects, its function is to grind and also for finishing. [7] In the research that has been done, the author chooses to display the test of the belt grinding that has been made to the material, speed, time, and size of the sharpened material, along with the results:

\subsection{Stainless Steel Test Results With 1 Minute Time}

Stainless Steel is widely used in industry, Stainless Steel is resistant to rust [8]. As a result of the passivity, phenomenon makes Stainless Steel resistant to corrosion, but actually, Stainless Steel can experience uniform corrosion, cracks, and stress corrosion [9]. Stainless steel is a metal with an iron base material that has a content of at least $11 \%$ chromium with or without other metal alloys. The basic composition of stainless steel is iron (Fe) and chromium (Cr) this is the simplest form of stainless steel [10]. Data from the test results that have been entered into the table, then the author describes the form of the test 
results in the form of a graph, the following results of testing stainless steel materials with a time of 1 minute can be seen in Figure 2 below.

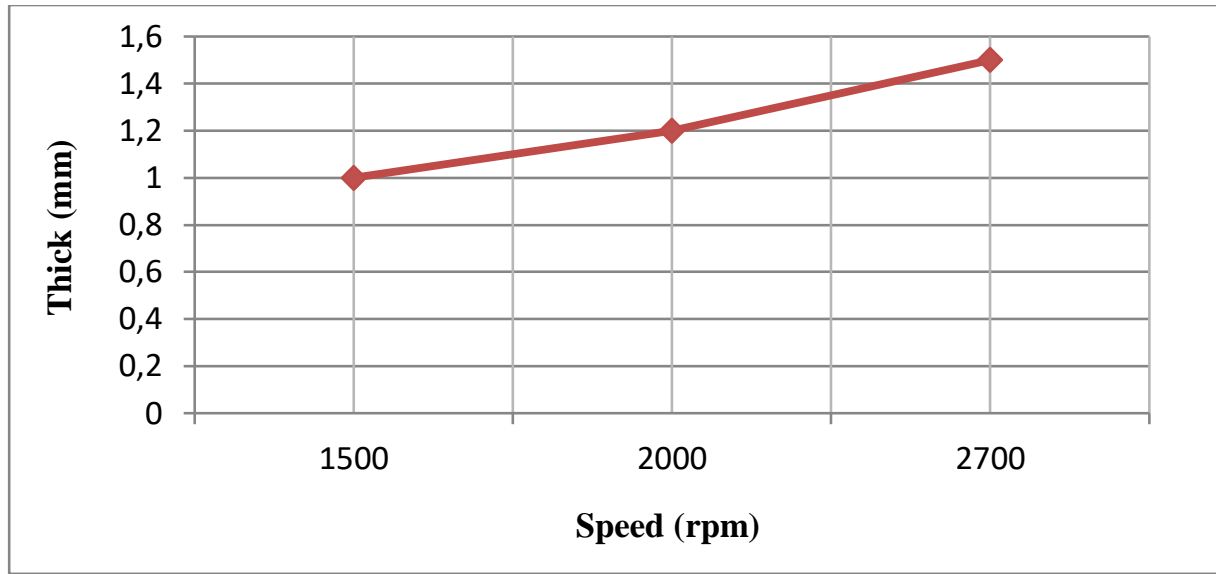

Fig. 2. Graph of Stainless Steel Testing Results with 1 Minute Time

Figure 2 above, can be seen the faster the rotation of the belt grinding machine, the thicker the incision in Stainless Steel with 1 minute time. This is because the rapid rotation of grinding will make the compression process by the belt sandpaper faster and will require less time to slash at a certain thickness.

\subsection{Steel Test Results for ST 37 with 1 minute time}

The element that most affects steel is carbon, but other elements cannot be ignored [11]. Baja St 37 is medium carbon steel and is equivalent to AISI 1045, St 37 steel can generally be directly used without the need to experience heat treatment [12]. Based on the data from the test results, the following results of testing st 37 steel material with a time of 1 minute can be seen in Figure 3 below.

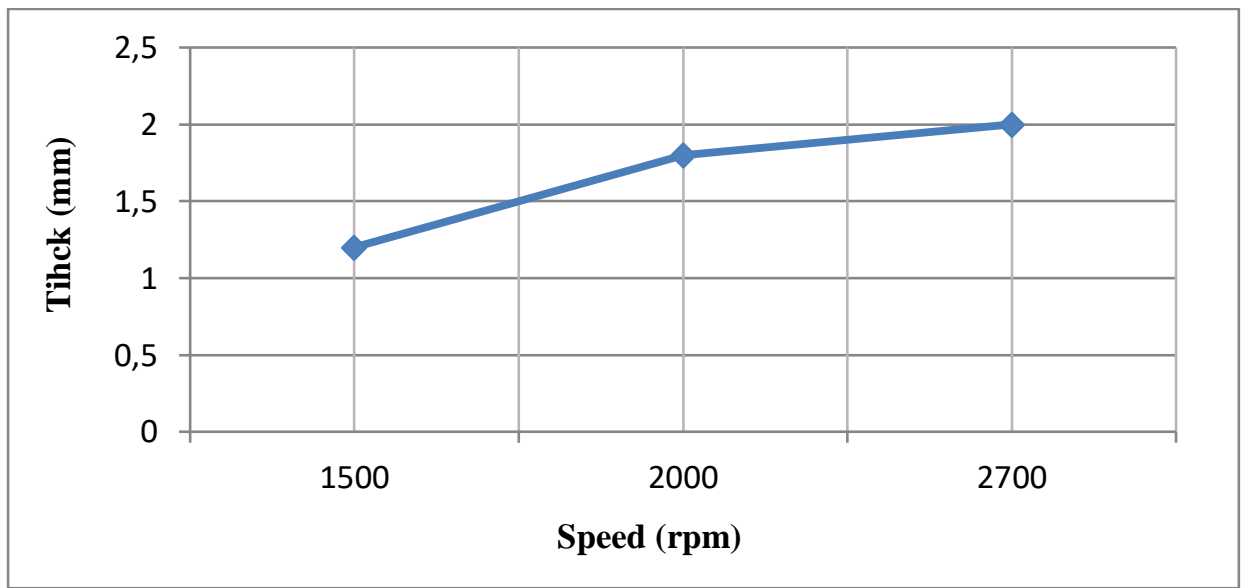

Fig. 3. Graph of Steel Test Results for ST 37 with 1 Minute time

Figure 3 above, can be seen the faster the rotation of the belt grinding machine, the deeper the incision thickness in Steel ST37 with 1 minute time. This is because the rapid rotation of grinding will make the compression process by the belt sandpaper faster and will require less time to slash at a certain thickness.

\subsection{Wood Material Testing Results in 1 Minute}

The nature of teak is strong, durable, stable, and easily shaped and its unique pattern makes teak wood most in demand [13]. Data from the test results that have been entered into the table, then the author describes the form of test results in graphical form. The following results of the testing of wood materials with a time of 1 minute can be seen in Figure 4 below. 


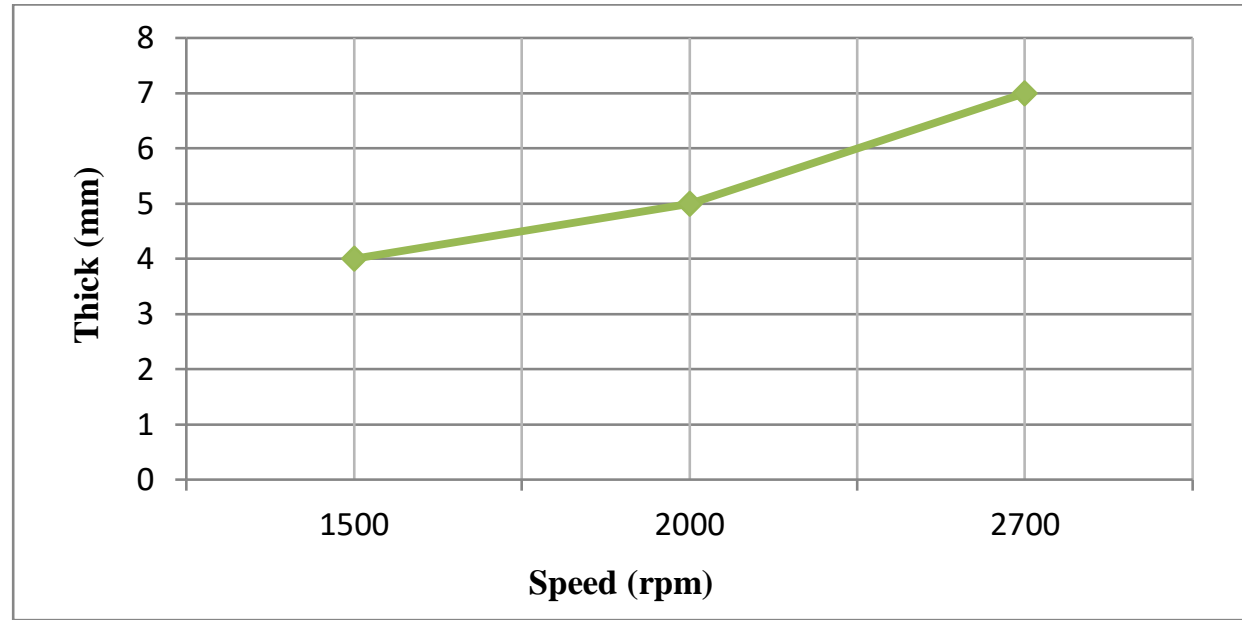

Fig. 4. Graph of Testing Results for Wood Materials with 1 Minute Time

Figure 4 above, can be seen the faster the rotation of the belt grinding machine, the deeper the incision thickness in Wood with 1 minute time. This is because the rapid rotation of grinding will make the compression process by the belt sandpaper faster and will require less time to slash at a certain thickness.

\subsection{Comparison of Stainless Steel, Steel ST 37, and Wood Using the Same Speed (2700 RPM)}

Stainless steel is known as stainless steel, corrosion resistant steel because the minimum alloy element is $18 \%$ chromium and $8 \%$ nickel. However, it can actually experience certain types of corrosion [14]. One by one the comparison of the time difference with the incision thickness of the three materials, then the comparison of stainless steel material, steel st37, and wood using the same speed (2700 RPM) the results can be seen in Figure 5 below.

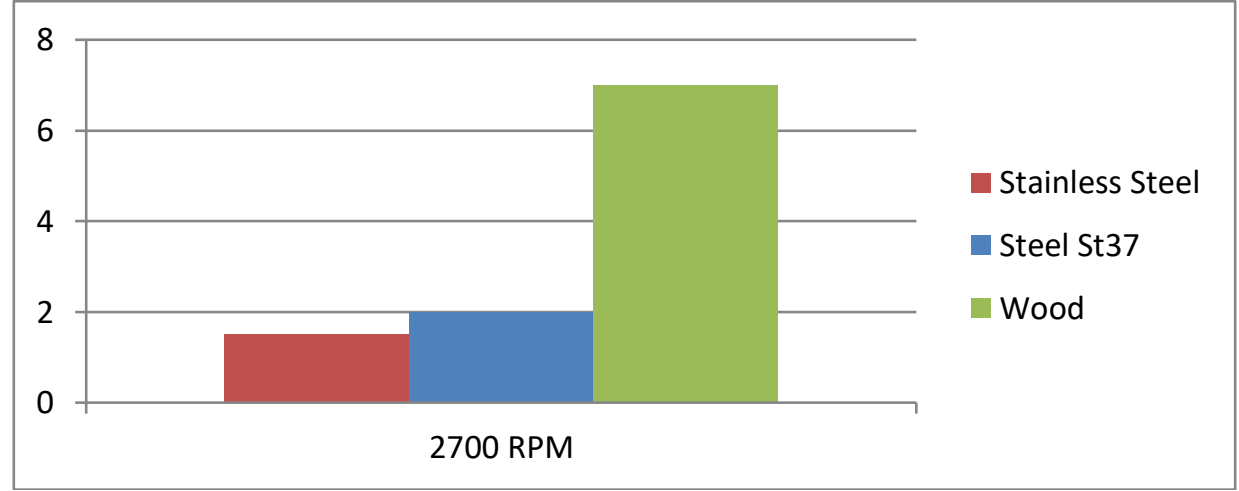

Fig. 5 Comparison of Stainless Steel, St 37, and Wood Using the Same Speed (2700 RPM)

Figure 2, 3, 4, we have seen that the faster the rotation, the deeper the incision thickness at the same time, then in Figure 5 we see how the thickness of the incision between stainless steel, ST37 steel, and wood at the same speed and with the same time. We can see Figure 4 and conclude that stainless steel is the hardest material followed by ST37 steel, and finally wood is the softest material when viewed from the thickness of the incision produced at the same time. We can also see (4) that the ratio of the thickness of the incision is not too far between the stainless steel material and the steel material st37, the difference is $0.5 \mathrm{~mm}$. This is because the difference in hardness between stainless steel and steel material st37 is not too far compared to wood material which can be seen that the difference in thickness of the incision with st37 steel is $5.5 \mathrm{~mm}$.

This test uses the sharpening slope angle 00 in the sense of "flat" or perpendicular to the belt grinder, but in fact this sharpening angle can be tilted, just like sharpening a blade, but the inclined sharpening method results in an uneven contact area with the belt grinder both from stainless steel, st37 steel, and wood, which will reduce the accuracy of the test results that the author did. We can conclude this test that stainless steel is harder than steel st37, and wood is much softer than steel st37. Speed greatly affects the time in 
grinding the faster it takes the time it takes, the less grinding. The advantages of this belt grinding are fine work or finishing. With high accuracy, we can be more accurate to form an object to be a more precise size.

\section{CONCLUSION}

The results of the research and discussion can be taken the first few conclusions, The advantages of belt grinding machines are in finishing work not in rough workmanship. Second, the rotating speed of the belt grinding machine is directly proportional to the speed of incision by the belt grinding machine. Lastly, the disadvantage of this belt grinding machine is that it is less effective in rough working and deep cutting, and also the weakness of the belt sandpaper which can be damaged if the rotation is less stable.

\section{REFERENCES}

[1] M. Ngafifi, "Advances in Technology and Patterns of Human Life in Socio-Cultural Perspective," Kemajuan Teknol. dan Pola Hidup Mns., vol. 2, no. 1, pp. 33-47, 2014.

[2] S. Arikunto, Prosedur Penelitian Suatu pendekatan Praktek. 2006.

[3] Y. hadi Miarso, Media Instruksional. Jakarta: Pusat TKPK Depdikbud, 1985.

[4] J. Adri and Refdinal, "Aplikasi Teknologi Tepat Guna Thereser Multiguna Untuk Petani Padi Daerah Perbatasan Dharmasraya," vol. 18, no. 2, 2018.

[5] Arwizet, "Mesin destilasi pengolahan sampah plastik menjadi bahan bakar minyak menggunakan kondensor bertingkat dan pendingin kompresi uap," vol. 17, no. 2, 2017.

[6] H. Nurdin, "Karakteristik Nilai Kalor Briket Tebu Tibarau Sebagai Bahan Bakar Alternatif," vol. 18, no. 1, pp. 19-24, 2018.

[7] F. Wijanarko, B. W. F, and Masyrukan, "Pengaruh Penggunaan Perekat Epoxy Dan Phenolic Terhadap Kekuatan Impak Dan Keausan Pada Pembuatan Batu Gerinda,” pp. 1-5, 2016.

[8] S. M. B. Respati, "Bahan Biomaterial Stainless Steel Dan Keramik,” Momentum, vol. 6, no. 1, pp. 58, 2010.

[9] A. Hilmi and D. H. Sutjahjo, “Analisa Laju Korosi Pada Stainless Steel 430 Menggunakan Metode Astm G31-72 Pada Media Air Nira Lontar," 2015.

[10] M. Muslim and S. Yosferi, "Peningkatan Kualitas Permukaan Pada Stainless Steel 3161," vol. 7, no. 2, pp. 141-145, 2014.

[11] B. Syahri, Z. A. Putra, N. Helmi, T. Mesin, F. Teknik, and U. N. Padang, "Perlakuan Panas Hardening Dan Media Pendingin Hardness Analysis of Steel Assab 705 Given That Hardening Heat Treatment and Cooling Medium," vol. 17, no. 1, pp. 17-26, 2017.

[12] S. Kirono and A. Amri, "Pengaruh Tempering Pada Baja ST 37 Yang Mengalami Karburasi Dengan Bahan Padat Terhadap Sifat Mekanis dan Struktur Mikro,” Jur. Mesin, Univ. Muhammadiyah Jakarta, no. C, pp. 1-10.

[13] I. Wahyudi, T. Priadi, and I. S. Rahayu, "Karakteristik dan Sifat-Sifat Dasar Kayu Jati Unggul Umur 4 dan 5 Tahun Asal Jawa Barat (Characteristics and Basic Properties of 4 and 5 year-old of Superior Teakwoods from West Java)," J. Ilmu Pertan. Indones., vol. 19, no. 1, pp. 50-56, 2014.

[14] R. Ornelasari, “Analisa Laju Korosi Pada Stainless Steel 304 Menggunakan Metode Astm G31-72 Pada Media Air Nira Aren," Pendidik. Tek. Mesin Fak. Tek. Univ. Negeri Surabaya, vol. 01, pp. $112-117,2015$. 